\title{
Pengaruh Variasi Campuran Bioetanol dengan Pertalite terhadap Bentuk dan Warna Api
}

\author{
Hardyansah Satria Putra ${ }^{(1)}$ \\ ${ }^{1}$ Universitas Nahdlatul Ulama Blitar \\ Email: ${ }^{1}$ hardyansahs@unublitar.com
}

\begin{tabular}{l}
\hline Tersedia Online di \\
\hline http://www.jurnal.unublitar.ac.id/ \\
index.php/briliant
\end{tabular}

Sejarah Artikel

Diterima pada 5 April 2018

Disetuji pada 5 Mei 2018

Dipublikasikan pada 13 Mei

2018 Hal. 213-219

\section{Kata Kunci:}

bioethanol, pertalite, warna,

bentuk api, waktu rambat api,

\section{DOI:}

http://dx.doi.org/10.28926/briliant .v3i2.168

\begin{abstract}
Abstrak: Bioethanol adalah senyawa bio ethyl alcohol $(\mathrm{C} 2 \mathrm{H} 5 \mathrm{OH})$ berupa cairan bening tak berwarna, terurai secara biologis (biodegradable), memiliki nilai oktan tinggi dan dapat menggantikan timbal dalam bahan bakar fosil, dengan mencampurkan bioethanol kedalam bahan bakar fosil akan mengoksigenasi campuran bahan bakar sehingga dapat terbakar dengan lebih sempurna, kadar bioethanol yang digunakan dalam penelitian ini adalah ethanol $99 \%$ dengan percampuran antara bahan bakar fosil (Pertalite) dengan bioethanol $20 \%, 25 \%$. 30\%, $45 \%$ dalam tabung pembakaran dari proses pembakaran tersebut didapatkan warna api dan bentuk api dari masing-masing campuran, untuk warna api yang memiliki warna lebih biru dan kecepatan api lebih cepat berada pada campuran $30 \%$ - $45 \%$ dengan demikian dapat dinyatakan bahwa campuran $30 \%-45 \%$ dapat digunakan dan diteliti lebih lanjut.
\end{abstract}

Pada saat ini pemakaian motor bensin dari tahun ke tahun semakin meningkat hal ini mengakibatkan pemakaian bahan bakar minyak bumi semakin meningkat dan tentu sangat mengkhawatirkan, karena dengan peningkatan pemakaian bahan bakar minyak bumi maka cadangan minyak bumi akan semakin berkurang sedangkan kebutuhan akan minyak terus bertambah. Keadaan diatas juga tidak sesuai dengan kebijakan pemerintah dibidang energi, yang mengusahakan pemakian bahan bakar minyak bumi yang sehemat-hematnya, mengingat minyak bumi merupakan sumber energy yang tidak dapat diperbaharui. Krisis energi ini menyebabkan manusia beralih pola pikir untuk lebih mengintensifkan penelitian dan penggunaan dari energy yang tidak terbarukan ke energi yang terbarukan (Taryono,2006).

Salah satu energi tebarukan tersebut adalah berasal dari bio massa yang diproses menjadi etanol. Etanol atau etil alcohol (lebih dikenal sebagai alcohol) adalah cairan berwarna dengan karakteristik antara lain mudah terbakar, larut dalam air, dan jika terjadi pencemaran tidak memberikan dampak lingkungan yang signifikan. Penggunaan etanol sebagai bahan bakar bernilai oktan tinggi atau adtif meningkat bilangan oktan pada bahan bakar

Namun demikian ethanol bersifat polar sehingga kurang baik bercampur dengan bahan bakar yang non polar, dimana pencampuran antara ethanol dan bahan bakar fosil dapat dicampurkan dalam fase uap sebelum masuk kedalam ruang bakar dengan teknologi Electronic Ethanol Injection maka pencampuran bioethanol dan bahan bakar fosil dapat dicampurkan. 


\section{METODE}

Salah satu bahan bakar yang dapat digunakan untuk menggantikan bensin adalah etanol dimana ethanol yang biasa disebut etil alcohol $(\mathrm{C} 2 \mathrm{H} 5 \mathrm{OH})$ bersifat cair yang memiliki bilangan Oktan yang lebih tinggi dibandingkan dengan bahan bakar fosil sehingga memungkinkan penggunaan ratio kompresi yang lebih tinggi pada mesin Otto, dimana pada mesin Otto yang menggunakan bioethanol secara keseluruhan memiliki efisiensi yang lebih tinggi dibandingkan dengan menggunakan bahan bakar fosil (Yuksel.dkk,2004).

Dari kajian pustaka diatas maka dilakukan penelitian untuk mencari alternatif bahan bakar yang renewable yang dapat meninggkatkan nilai efisiensi dari mesin Otto tanpa harus melakukan modifikasi, serta melakukan penelitian terhadap bentuk api, kecepatan api yang terjadi pada setiap variasi campuran bioethanol dengan bahan bakar fosil.

Dimana kecepatan api sangat mempengaruhui daya dorong dari hasil pembakaran campuran bioethanol dan bahan bakar berubah menjadi gaya gerak yang menggerakan komponen lain dalam mesin Otto, sehingga kecepatan api sangat diperlukan untuk mengetahui campuran variasi yang mendekati stokiometri serta memiliki nilai efisiensi yang lebih tinggi terhadap mesin Otto. perbandingan ekuivalen bahan bakar dan udara adalah

$$
\begin{gathered}
\lambda=\frac{\left(\frac{A}{F}\right) \text { actual }}{\left(\frac{A}{F}\right) \text { teoritis }} \\
\text { Dimana }: \lambda<1=\text { Campuran Miskin } \\
\lambda=1=\text { Campuran Ideal (Stoikiometri) } \\
\lambda>1=\text { Campuran Kay }
\end{gathered}
$$

HASIL

Pengujian campuran 80:20
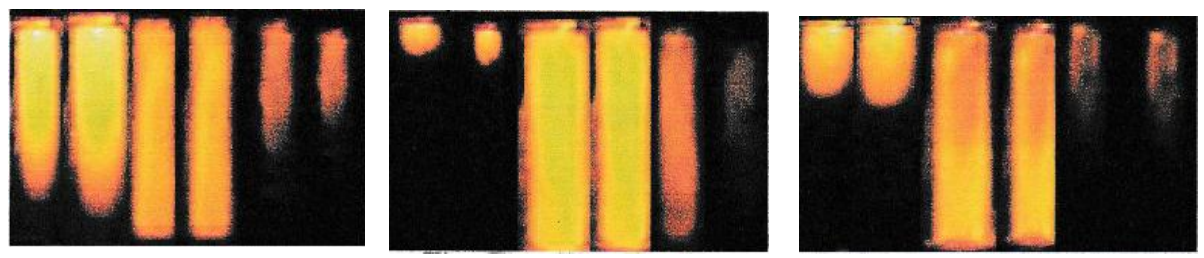

Gambar 1 Bentuk Warna Api Campuran 80:20 
Tabel 1 Kecepatan Campuran 80:20

\begin{tabular}{|r|l|l|l|l|r|r|}
\hline EQUIVALEN & \multicolumn{7}{|c|}{ Pengujian } \\
\cline { 2 - 7 } RATIO & 1 & 2 & 3 & 4 & 5 & Rata-rata \\
\hline 1.05 & 0.526 & 0.518 & 0.510 & 0.502 & 0.494 & 0.720 \\
\hline 0.89 & 0.525 & 0.517 & 0.509 & 0.501 & 0.493 & 0.687 \\
\hline 0.60 & 0.524 & 0.516 & 0.508 & 0.500 & 0.492 & 0.629 \\
\hline 0.49 & 0.523 & 0.515 & 0.507 & 0.499 & 0.491 & 0.605 \\
\hline 0.38 & 0.522 & 0.514 & 0.506 & 0.498 & 0.490 & 0.582 \\
\hline
\end{tabular}

Tabel 2 Waktu Rambat Api Campuran 80:20

\begin{tabular}{|c|c|c|c|c|c|c|}
\hline \multirow{2}{*}{$\begin{array}{l}\text { EQUIVALEN } \\
\text { RATIO }\end{array}$} & \multicolumn{6}{|c|}{ Pengujian } \\
\hline & 1 & 2 & 3 & 4 & 5 & Rata-rata \\
\hline 1.05 & 3148.67 & 3125.43 & 3102.19 & 3078.95 & 3055.71 & 3102.19 \\
\hline 0.89 & 2816.69 & 2793.45 & 2770.21 & 2746.97 & 2723.73 & 2770.21 \\
\hline 0.60 & 2638.35 & 2615.11 & 2591.87 & 2568.63 & 2545.39 & 2591.87 \\
\hline 0.49 & 2360.01 & 2336.77 & 2313.53 & 2290.29 & 2267.05 & 2313.53 \\
\hline 0.38 & 2081.67 & 2058.43 & 2035.19 & 2011.95 & 1988.71 & 2035.19 \\
\hline
\end{tabular}

\section{Pengujian campuran 75:25}
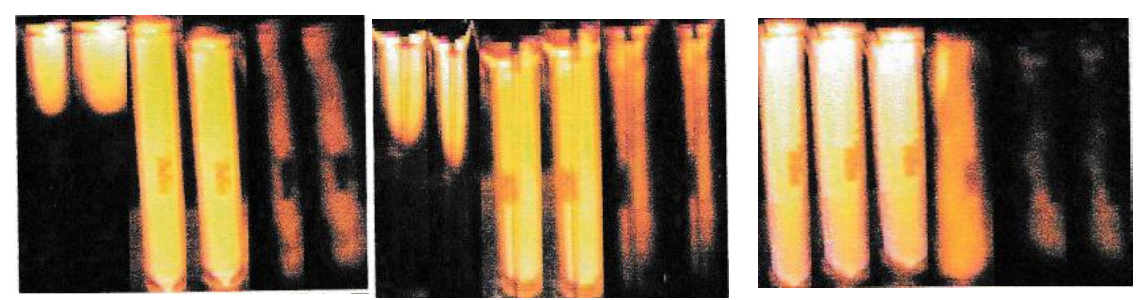

Gambar 2 Bentuk Warna Api Campuran 75:25

Tabel 3 Kecepatan Campuran 75:25

\begin{tabular}{|c|c|c|c|c|c|c|}
\hline \multirow{2}{*}{$\begin{array}{c}\text { EQUIVALEN } \\
\text { RATIO }\end{array}$} & \multicolumn{7}{|c|}{ Pengujian } \\
\cline { 2 - 7 } & 1 & 2 & 3 & 4 & 5 & Rata-rata \\
\hline 1.05 & 3348.79 & 3325.55 & 3302.31 & 3279.07 & 3255.83 & 3302.31 \\
\hline 0.89 & 3016.81 & 2993.57 & 2970.33 & 2947.09 & 2923.85 & 2970.33 \\
\hline 0.60 & 2838.47 & 2815.23 & 2791.99 & 2768.75 & 2745.51 & 2791.99 \\
\hline 0.49 & 2560.13 & 2536.89 & 2513.65 & 2490.41 & 2467.17 & 2513.65 \\
\hline 0.38 & 2281.79 & 2258.55 & 2235.31 & 2212.07 & 2188.83 & 2235.31 \\
\hline
\end{tabular}

Tabel 4 Waktu Rambat api Campuran 75:25

\begin{tabular}{|r|l|l|l|l|l|r|}
\hline \multirow{2}{*}{$\begin{array}{c}\text { EQUIVALEN } \\
\text { RATIO }\end{array}$} & \multicolumn{7}{|c|}{ Pengujian } \\
\cline { 2 - 7 } & 1 & 2 & 3 & 4 & 5 & Rata-rata \\
\hline 1.05 & 0.559 & 0.551 & 0.543 & 0.535 & 0.527 & 0.754 \\
\hline 0.89 & 0.558 & 0.550 & 0.542 & 0.534 & 0.526 & 0.721 \\
\hline 0.60 & 0.557 & 0.549 & 0.541 & 0.533 & 0.525 & 0.662 \\
\hline 0.49 & 0.556 & 0.548 & 0.540 & 0.532 & 0.524 & 0.639 \\
\hline 0.38 & 0.555 & 0.547 & 0.539 & 0.531 & 0.523 & 0.616 \\
\hline
\end{tabular}

215 BRILIANT: Jurnal Riset dan Konseptual

Volume 3 Nomor 2, Mei 2018 


\section{Pengujian campuran 70:30}
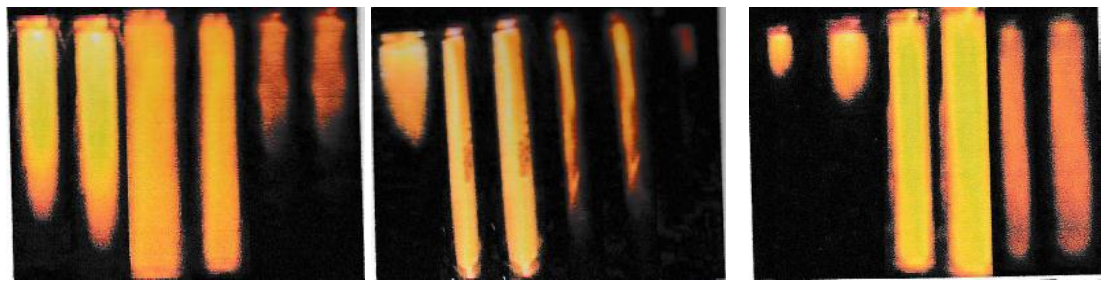

Gambar 3 Bentuk Warna Api Campuran 70:30

Tabel 5 Kecepatan Campuran 70:30

\begin{tabular}{|c|c|c|c|c|c|c|}
\hline \multirow{2}{*}{$\begin{array}{c}\text { EQUIVALEN } \\
\text { RATIO }\end{array}$} & \multicolumn{6}{|c|}{ Pengujian } \\
\hline & 1 & 2 & 3 & 4 & 5 & Rata-rata \\
\hline 1.05 & 3562.46 & 3539.22 & 3515.98 & 3492.74 & 3469.50 & 3515.98 \\
\hline 0.89 & 3230.48 & 3207.24 & 3184.00 & 3160.76 & 3137.52 & 3184.00 \\
\hline 0.60 & 3052.14 & 3028.90 & 3005.66 & 2982.42 & 2959.18 & 3005.66 \\
\hline 0.49 & 2773.80 & 2750.56 & 2727.32 & 2704.08 & 2680.84 & 2727.32 \\
\hline 0.38 & 2495.46 & 2472.22 & 2448.98 & 2425.74 & 2402.50 & 2448.98 \\
\hline
\end{tabular}

Tabel 6 Waktu Rambat Campuran 70:30

\begin{tabular}{|c|c|c|c|c|c|c|}
\hline \multirow{2}{*}{$\begin{array}{c}\text { EQUIVALEN } \\
\text { RATIO }\end{array}$} & \multicolumn{6}{|c|}{ Pengujian } \\
\hline & 1 & 2 & 3 & 4 & 5 & Rata-rata \\
\hline 1.05 & 0.595 & 0.587 & 0.579 & 0.571 & 0.563 & 0.789 \\
\hline 0.89 & 0.594 & 0.586 & 0.578 & 0.570 & 0.562 & 0.757 \\
\hline 0.60 & 0.593 & 0.585 & 0.577 & 0.569 & 0.561 & 0.698 \\
\hline 0.49 & 0.592 & 0.584 & 0.576 & 0.568 & 0.560 & 0.675 \\
\hline 0.38 & 0.591 & 0.583 & 0.575 & 0.567 & 0.559 & 0.651 \\
\hline
\end{tabular}

\section{Pengujian campuran 65:35}
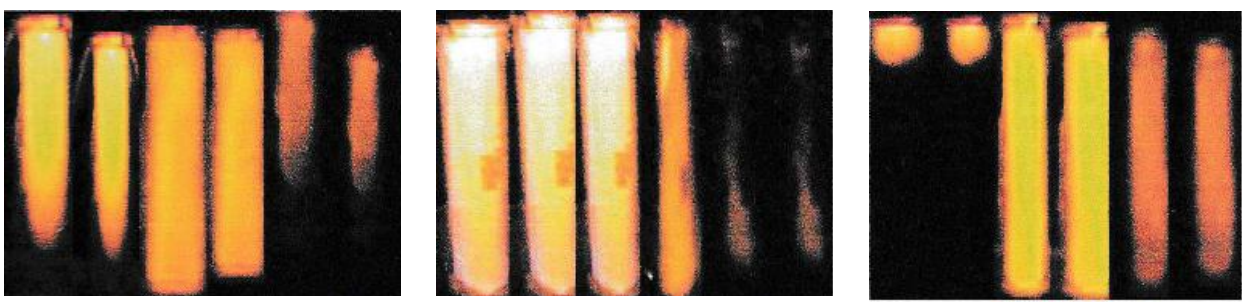

Gambar 4 Bentuk Warna Api Campuran 65:35

Tabel 7 Kecepatan Campuran 65:35

\begin{tabular}{|c|c|c|c|c|c|c|}
\hline \multirow{2}{*}{$\begin{array}{c}\text { EQUIVALEN } \\
\text { RATIO }\end{array}$} & \multicolumn{7}{|c|}{ Pengujian } \\
\cline { 2 - 7 } & 1 & 2 & 3 & 4 & 5 & Rata-rata \\
\hline 1.05 & 3776.13 & 3752.89 & 3729.65 & 3706.41 & 3683.17 & 3729.65 \\
\hline 0.89 & 3444.15 & 3420.91 & 3397.67 & 3374.43 & 3351.19 & 3397.67 \\
\hline 0.60 & 3265.81 & 3242.57 & 3219.33 & 3196.09 & 3172.85 & 3219.33 \\
\hline 0.49 & 2987.47 & 2964.23 & 2940.99 & 2917.75 & 2894.51 & 2940.99 \\
\hline 0.38 & 2709.13 & 2685.89 & 2662.65 & 2639.41 & 2616.17 & 2662.65 \\
\hline
\end{tabular}


Tabel 8 Waktu Rambat Campuran 65:35

\begin{tabular}{|r|c|l|l|l|l|r|}
\hline \multirow{2}{*}{$\begin{array}{c}\text { EQUIVALEN } \\
\text { RATIO }\end{array}$} & \multicolumn{7}{|c|}{ Pengujian } \\
\cline { 2 - 7 } & 1 & 2 & 3 & \multicolumn{1}{c|}{4} & 5 & Rata-rata \\
\hline 1.05 & 0.631 & 0.623 & 0.615 & 0.607 & 0.599 & 0.825 \\
\hline 0.89 & 0.630 & 0.622 & 0.614 & 0.606 & 0.598 & 0.792 \\
\hline 0.60 & 0.629 & 0.621 & 0.613 & 0.605 & 0.597 & 0.734 \\
\hline 0.49 & 0.628 & 0.620 & 0.612 & 0.604 & 0.596 & 0.710 \\
\hline 0.38 & 0.627 & 0.619 & 0.611 & 0.603 & 0.595 & 0.687 \\
\hline
\end{tabular}

\section{Pengujian campuran 55:45}
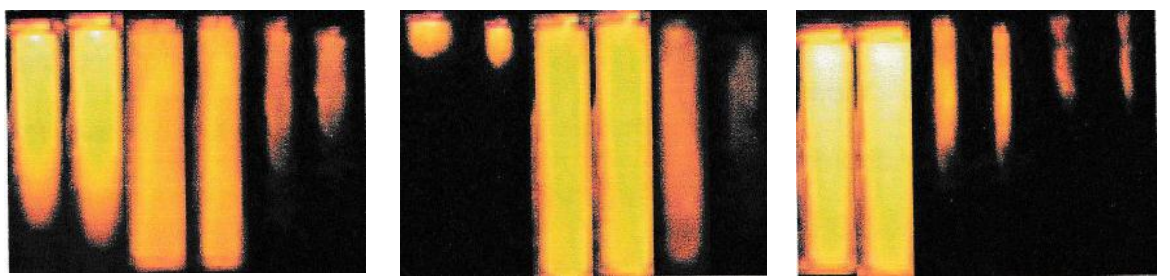

Gambar 5 Bentuk Warna Api Campuran 55:45

Tabel 9 Kecepatan Campuran 55:45

\begin{tabular}{|c|c|c|c|c|c|c|}
\hline \multirow{2}{*}{$\begin{array}{c}\text { EQUIVALEN } \\
\text { RATIO }\end{array}$} & \multicolumn{7}{|c|}{ Pengujian } \\
\cline { 2 - 7 } & 1 & 2 & 3 & 4 & 5 & Rata-rata \\
\hline 1.05 & 3989.80 & 3966.56 & 3943.32 & 3920.08 & 3896.84 & 3943.32 \\
\hline 0.89 & 3657.82 & 3634.58 & 3611.34 & 3588.10 & 3564.86 & 3611.34 \\
\hline 0.60 & 3479.48 & 3456.24 & 3433.00 & 3409.76 & 3386.52 & 3433.00 \\
\hline 0.49 & 3201.14 & 3177.90 & 3154.66 & 3131.42 & 3108.18 & 3154.66 \\
\hline 0.38 & 2922.80 & 2899.56 & 2876.32 & 2853.08 & 2829.84 & 2876.32 \\
\hline
\end{tabular}

Tabel 10 Waktu Rambat Campuran 55:45

\begin{tabular}{|r|r|l|l|l|l|r|}
\hline \multirow{2}{*}{$\begin{array}{c}\text { EQUIVALEN } \\
\text { RATIO }\end{array}$} & \multicolumn{7}{|c|}{ Pengujian } \\
\cline { 2 - 7 } & 1 & 2 & 3 & 4 & 5 & Rata-rata \\
\hline 1.05 & 0.666 & 0.658 & 0.650 & 0.642 & 0.634 & 0.861 \\
\hline 0.89 & 0.665 & 0.657 & 0.649 & 0.641 & 0.633 & 0.828 \\
\hline 0.60 & 0.664 & 0.656 & 0.648 & 0.640 & 0.632 & 0.769 \\
\hline 0.49 & 0.663 & 0.655 & 0.647 & 0.639 & 0.631 & 0.746 \\
\hline 0.38 & 0.662 & 0.654 & 0.646 & 0.638 & 0.630 & 0.723 \\
\hline
\end{tabular}

\section{PEMBAHASAN}

Hasil pengujian campuran bioethanol $20-45 \%$ dicampurkan dengan Pertalite dengan kandungan 55 - 80\% didapatkan hasil video yang di konversikan menjadi gambar dimana jumlah gambar yang dihasilkan dari konversi dibagikan dengan waktu yang di gunakan untuk proses pengujian. Dari hasil visualisasi didapatkan bahwa hasil pencampuran bahan bakar fosil ditambahkan dengan bioethanol dengan kadar yang ditetapkan serta dilakukan pembakaran dengan 
kadar udara yang telah ditentukan untuk mendapatkan AFR tertentu dimana dapat dilihat bahwa AFR yang mendekati stoikiometri adalah pada AFR 1,05 dan yang terendah pada AFR 0,38. Selain dari AFR yang telah ditentukan dapat dilihat bahwa pengujian yang menggunakan percampuran bahan bakar dan bioethanol lebih tinggi akan memiliki kecepatan dan waktu rambat yang lebih cepat dibandingkan dengan campuran bahan bakar dan bioethanol yang lebih rendah. Dari hasil visualisasi didapatkan kecepatan api yng dihasilkan dari pencampuran bahan bakar fosil ditambahkan dengan bioethanol dengan kadar yang ditetapkan serta dilakukan pembakaran dengan kadar udara yang telah ditentukan untuk mendapatkan AFR tertentu dimana dapat dilihat bahwa AFR yang mendekati stoikiometri adalah pada AFR 1,05 dan yang terendah pada AFR 0,38.

Selain dari AFR yang telah ditentukan dapat dilihat bahwa pengujian yang menggunakan percampuran bahan bakar dan bioethanol lebih tinggi akan memiliki kecepatan rambat api yang lebih cepat dibandingkan dengan campuran bahan bakar dan bioethanol yang lebih rendah. Dari hasil visualisasi didapatkan waktu rambat api yng dihasilkan dari pencampuran bahan bakar fosil ditambahkan dengan bioethanol dengan kadar yang ditetapkan serta dilakukan pembakaran dengan kadar udara yang telah ditentukan untuk mendapatkan AFR tertentu dimana dapat dilihat bahwa AFR yang mendekati stoikiometri adalah pada AFR 1,05 dan yang terendah pada AFR 0,38. Selain dari AFR yang telah ditentukan dapat dilihat bahwa pengujian yang menggunakan percampuran bahan bakar dan bioethanol lebih tinggi akan memiliki waktu rambat api yang lebih cepat dibandingkan dengan campuran bahan bakar dan bioethanol yang lebih rendah.

\section{KESIMPULAN}

Bentuk dan warna api yang dihasilkan pada tiap pengujian dengan variabel campuran yang berbeda akan memiliki warna yang berbeda pula dimana warna api yang dihasilkan tergantung pada beberapa hal yaitu Air Fuel Ratio (AFR) serta jumlah/kadar campuran bioethanol dalam tiap pengujian, dimana hasil yang mendekati stoikiometri dalam setiap varian campuran berada pada AFR 1,05 serta warna api yang mendekati stokiometri berada pada campuran 55: 45. Kecepatan yang dihasilkan pada tiap pengujian dengan variabel campuran yang berbeda akan memiliki kecepatan yang berbeda pula dimana kecepatan api yang dihasilkan tergantung pada beberapa hal yaitu Air Fuel Ratio (AFR) serta jumlah/kadar campuran bioethanol dalam tiap pengujian, dimana hasil yang mendekati stoikiometri dalam setiap varian campuran berada pada AFR 1,05 serta warna api yang mendekati stokiometri berada pada campuran 55: 45. Waktu rambat api yang dihasilkan pada tiap pengujian dengan variabel campuran yang berbeda akan memiliki waktu rambat api yang berbeda pula dimana waktu rambat api yang dihasilkan tergantung pada beberapa hal yaitu Air Fuel Ratio (AFR) serta jumlah/kadar campuran bioethanol dalam tiap pengujian, dimana hasil yang mendekati stoikiometri dalam setiap varian campuran berada pada AFR 1,05 serta warna api yang mendekati stokiometri berada pada campuran 55: 45. Dari hasil analisa yang kami lakukan didapatkan campuran yang direkomendasikan untuk dilakukan pengujian lebih lanjut yaitu pada campuran 65:35 dan 55:45 


\section{SARAN}

Penggunaan campuran bahan bakar ini masih perlu diperhitungkan biaya pembelian bahan bakar bagi masyarakat dimana produksi bioethanol yang masih sedikit oleh karena hal tersebut perlu diperhatikan untuk menambah jumlah produksi dari bioethanol sehingga dapat diterapkan. Dari hasil penelitian kami diperlukan pengujian emisi gas buang hasil pembakaran dari campuran bahan bakar dan bioethanol akan didapatkan seberapa besar tingkat pengurangan pencemaran lingkungan akibat emisi gas buang. Dari hasil penelitian dapat dilakukan penelitian lebih lanjut untuk daya dan tekanan pembakaran untuk dianalisa lebih lanjut.

\section{DAFTAR RUJUKAN}

Altin, R., Centikaya, S., \& Yucesu, S. 2002. The Potensial Of Using Vegetable Oil Fuel Fordiesel Engines.

Anonim, 2003. Biofuel, Altematif Pendamping bensin. BEI NEWS Edisi 12 Tahun IV Desember 2002-Januari 2003.

Wardana, 1.N.G. 2008. Bahan Bakar dan Teknologi Pembakaran'. Malang: Brawijaya University Press.

Putra, H.S. 2010. Pengaruh Variasi Campuran bioethanol terhadap Bentuk Dan Kecepatan Api Pada Silinder Shaw Cell. Tesis tidak diterbitkan. Malang: Universitas Brawijaya. 